\title{
The role of herbivorous water birds in aquatic systems through interactions with aquatic macrophytes, with special reference to the Bewick's Swan - Fennel Pondweed system
}

\author{
Marcel Klaassen · Bart A. Nolet
}

(C) Springer Science+Business Media B.V. 2007

\begin{abstract}
The role of aquatic macrophytes in stimulating biodiversity and maintaining clear waters is currently undisputed. The management of (eutrophic) shallow waters is therefore often directed at (re-)establishing macrophyte domination. In contrast, the role of water birds has long been considered of minor importance for the functioning of fresh water ecosystems. Indeed, in terms of biomass and production, water birds constitute only a minor part of these systems. However, water birds may graze heavily on water plants under certain circumstances, and the question arises whether herbivorous water birds have an important indirect effect on shallow fresh water systems. Mainly illustrated with the interaction between Bewick's Swans and Fennel Pondweed, we present data on the role that water plants may play in the life of water birds and how water birds may impact water plants' fitness in terms of survival, production, dispersal and competitive ability. It appears that water plants may
\end{abstract}

Guest editors: R. D. Gulati, E. Lammens, N. De Pauw \& E. Van Donk

Shallow lakes in a changing world

M. Klaassen $(\varangle) \cdot$ B. A. Nolet

Department of Plant-Animal Interactions, Centre for Limnology, Netherlands Institute of Ecology

(NIOO-KNAW), P. O. Box 1299, Maarssen 3600 BG,

The Netherlands

e-mail: m.klaassen@nioo.knaw.nl be crucial for water birds during periods of highenergy requirements, such as migration. Despite the plants' costs associated with water bird grazing, the interaction between water birds and water plants varies in nature from an apparent predator-prey relationship to a mutually beneficial interaction depending on the context and the perspective. For the case of the Bewick's Swan-Fennel Pondweed interaction, regular bird grazing is sustainable and may actually favour the plant's dispersal. Thus, Bewick's Swans themselves may in fact play a crucial role in establishing and maintaining the Fennel Pondweed rich staging sites between the swans' wintering and breeding grounds, which are vital for the swans' successful migration.

Keywords Bewick's Swan · Cygnus columbianus - Dispersal · Grazing · Plant competition · Plantherbivore interaction $\cdot$ Potamogeton pectinatus

\section{Introduction}

The structuring role of aquatic macrophytes in lakes, and in particular their importance as a food source, has long been underrated (Lodge, 1991). Less than a century ago, Shelford (1918) for instance wrote: "One could probably remove all the larger plants and substitute glass structures of the same form and surface structure without 
greatly affecting the immediate food relations". A more recent example is a statement like "macrophytes enter the food web only as detritus" (Polunin, 1984). The main argument was that losses due to herbivore grazing were usually small, between $0.5 \%$ and $8 \%$ of the total annual macrophyte production (Wetzel, 1983, p. 543). We now know that aquatic macrophytes in fact play important roles in freshwaters such as promoting a clear water state through the competition with algae and the stabilisation of the bottom sediment, enhancing biodiversity by offering shelter and substrate, and providing food for herbivorous water birds (Scheffer, 1998; Knapton \& Petrie, 1999; Engelhardt \& Ritchie, 2002; Noordhuis et al., 2002; Declerck et al., 2005). Nowadays, water managers strive for freshwater bodies dominated by aquatic macrophytes to fulfil these structuring functions and to support herbivorous water birds, which are often target species for management (Coops et al., 2002).

Conversely, effects of herbivores on aquatic macrophytes are generally still thought to be of minor importance. Only during the establishment phase, for instance after lake restoration, herbivorous water birds have been shown to delay colonization by aquatic macrophytes (Lauridsen et al., 1993; Søndergaard et al., 1996; Perrow et al., 1997; Lodge et al., 1998). Nevertheless, the lives of many aquatic macrophytes and their consumers may be importantly intertwined. Rather than trying to review the recent literature on the interaction between aquatic macrophytes and waterfowl, we present an overview of the possible facets of this fascinating interplay. We exemplify these various aspects of the interaction between grazing birds and macrophytes by the interaction between Fennel Pondweed (Potamogeton pectinatus) and Bewick's Swan (Cygnus columbianus bewickii), which we have studied in detail over the past decade.

\section{Bewick's Swans and their reliance on Fennel Pondweed}

Herbivorous waterfowl can be found all over the world but their breeding presence in the Arctic is particularly evident (Bellrose, 1980; Scott \&
Rose, 1996; Miyabayashi \& Mundkur, 1999). There they make up a large part of the avifauna having a considerable impact on the tundra vegetation (Person et al., 2003) and the functioning of the ecosystem as a whole (Kerbes et al., 1990; Jefferies et al., 1994, 2006). Each autumn these birds leave the Arctic in search of more benign environments to spend the winter. Most of the waterfowl breeding in the European Arctic and partly those breeding in Siberia and Greenland, aggregate in north-western Europe (Scott \& Rose, 1996). Tundra Swans (Cygnus columbianus) are circumpolar breeding, with Bewick's Swans (C. c. bewickii) breeding in northern Russia. The Netherlands appear to be very attractive to Bewick's Swans, with up to $70 \%$ of the population spending the winter there (Beekman, 1997). The attractiveness to these swans, and in fact many other species of waterfowl, probably lays in the country's relatively mild marine climate, the large availability of fresh water bodies and its agricultural production (Van Eerden et al., 2005). That The Netherlands is special in this latter respect can be exemplified by its fertiliser input, which is by far the highest in Europe with nearly $500 \mathrm{~kg}$ of N/ha of agricultural land per year (http://epp.eurostat.cec.eu.int).

If the attraction of The Netherlands for waterfowl partly lays in the readily available agricultural products and their harvest remains, what may then possibly be the role of water plants in the life of these birds and in return the birds' impact on water plants? Historic data on habitat use of Bewick's Swans in the 1930s reveals that at this time the swans in fact exclusively foraged on aquatic vegetation and notably Fennel Pondweed while wintering in The Netherlands (Brouwer \& Tinbergen, 1939). Fennel Pondweed is a pseudoannual highly relying on the production of asexual, starch-rich tubers to survive the winter. Bewick's Swans forage on these tubers by uprooting them from the sediment by trampling, subsequently sieving them from the sediment with their beak. Only after the explosion of agricultural production and accompanying decrease of submerged macrophytes in the 1960s and 1970s, Bewick's Swans were seen feeding on agricultural lands (Merne, 1972; Mullié \& Poorter, 1977). Being subsidised in this way, Bewick's Swans, like 
many other waterfowl species using agricultural resources, increased in population size (Abraham et al., 2005; Van Eerden et al., 2005). Despite the current great dependency on agricultural products relative to aquatic resources, the first food source to be selected by the swans after arrival in The Netherlands on their autumn migration are still Potamogeton tubers (Dirksen et al., 1991). To determine the diet choice of Bewick's Swans away from the wintering grounds we equipped 18 individuals with satellite transmitters. It appeared that both during spring and autumn migration Bewick's Swans spend most of their stop-over time in wetlands suggesting a great use of aquatic vegetation, notably Fennel Pondweed (Nolet et al., 2001; Beekman et al., 2002) (Fig. 1).

Using heart rate telemetry we estimated the energetic costs of aquatic and terrestrial foraging modes. It appeared that foraging energy expenditure alone could not explain the preference for aquatic habitats, since aquatic foraging was actually more expensive (38.9 Watt) than foraging on land (28.2 Watt). Next we estimated daily energy intake rates in free-living animals on a range of food sources. To this end we used a number of methods that mainly relied on measurements of dropping rates and estimates of grazing intensity in combination with food availability. We further measured energy assimilation in captive swans, which appeared to be highest (90\%) for pondweed tubers (Nolet et al., 2002). Depending on food availability, estimates of daily intake rates on grassland ranged up to $40 \mathrm{Watt}$, on crops (and their remains) up to $86 \mathrm{Watt}$, and on Fennel Pondweed tubers up to 136 Watt (Fig. 2). Daily energy intake rates on Fennel Pondweed are among the highest ever recorded in free-living birds. Not the rate of intake while feeding is so exceptional in tuber-foraging swans, but rather the time they can spend feeding per day. While on land, these heavy birds with their poor take-off abilities are potential prey for land predators such as foxes. Therefore, their safe foraging on land is precluded to the daylight hours. On water, however, they forage around the clock (Nolet \& Klaassen, 2005). As a result, the swans only leave the pondweed beds after these have been depleted down to the level that daytime beetfeeding becomes equally profitable (Beekman et al., 1991; Nolet et al., 2002).

We conclude that Bewick's Swans heavily feed on water plants during periods of high-energy demand, such as during migration, and that the availability of these resources is probably crucial in fulfilling their annual cycle. Whether swans, with their presumably high flight costs and their poor take-off abilities, and their need for highenergy food such as tubers, are exceptional in their reliance on aquatic resources requires further attention.

\section{Changing perspectives: Fennel Pondweed and its consumers}

Above we have argued that Bewick's Swans (and possibly other waterfowl) may greatly benefit from consuming water plants. The question is whether this consumer-resource relationship is purely antagonistic or whether there are also
Fig. 1 Breeding an wintering distribution of Bewick's Swan and the major stop-over sites used during migration in both spring and autumn. During migration Bewick's Swans heavily rely on wetlands where they preferentially forage on aquatic vegetation autumn

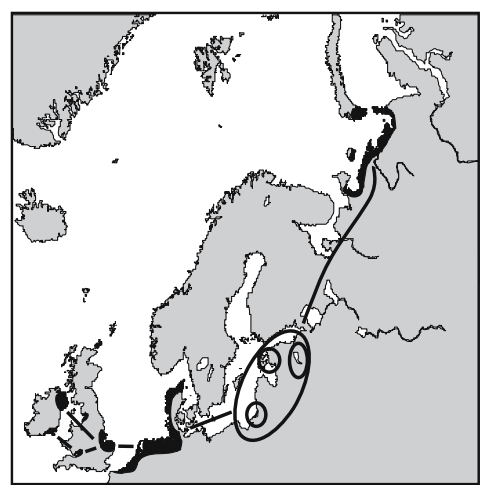

spring

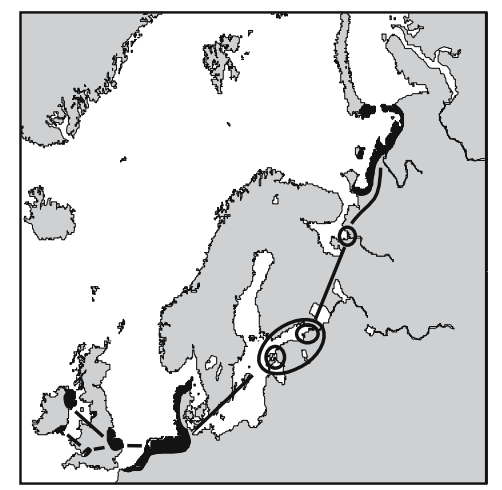




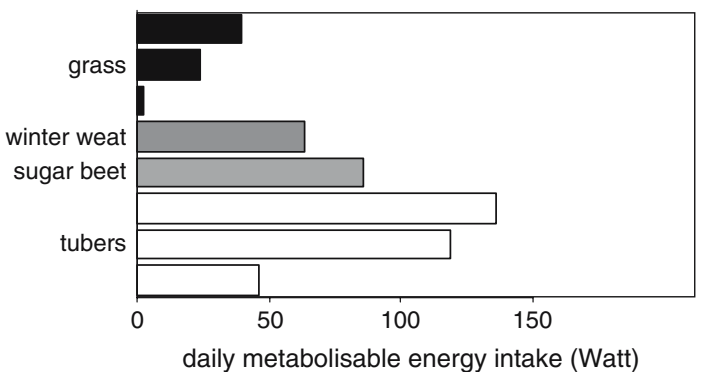

Fig. 2 Average daily metabolisable energy intake of freeliving Bewick's Swans feeding on grass (data from three different years/study sites), winter weat, sugar beet harvest remains and Fennel Pondweed tubers (data from three different years/study sites). Collated from data presented in Beekman et al. (2002)

aspects to it that are neutral and possibly mutualistic by nature?

\section{Plant defences against herbivores}

Plants may defend themselves in various ways against herbivore attack. Such defences may include chemical and structural defences, but also hiding in time (by being out of phase with the predator) and space. It is the latter that apparently happens in Fennel Pondweed when they are faced with increased predation pressure by tuber digging swans.

Fennel Pondweed tubers may easily vary one order of magnitude in volume (Santamaría \& Rodríguez-Gironés, 2002). For small tubers to sprout successfully they have to be in the upper sediment layers. However, given their larger stores, big tubers may successfully sprout from deep sediment layers (Fig. 3). Indeed, field data indicate that burial depth is positively related to tuber size in Fennel Pondweed. Still, to increase sprouting success one would expect tubers to be as high up in the sediment as possible. On the other hand, however, to avoid predation risk by swans and other waterfowl, tubers should be placed deep into the sediment (Nolet et al., 2006). Thus, for the plant there may be a trade off between tuber sprouting success and predation risk, resulting in a positive relationship between burial depth and tuber size (Santamaría \& Rodríguez-Gironés, 2002). In an area like Lauwersmeer, in the north of The Netherlands,

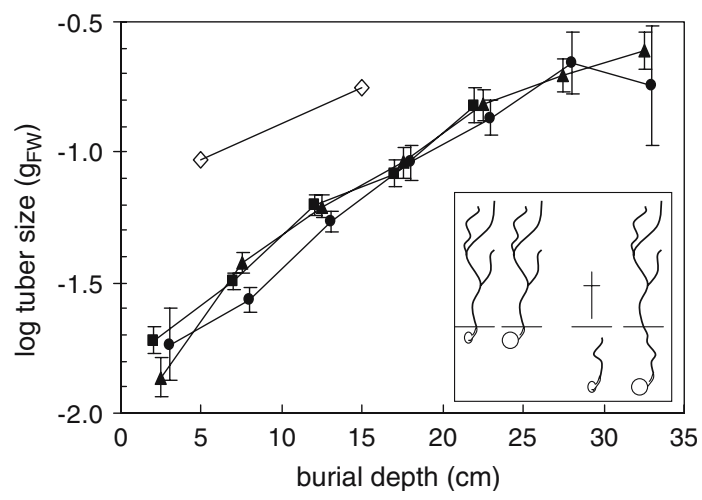

Fig. 3 Tuber size of Fennel Pondweed versus burial depth. Measurements are depicted from Lauwersmeer 1980 (open diamonds; Beekman et al., 1991), 1995 (closed squares \pm SD), 1996 (closed triangles) and 2003 (closed circles). The inset explains the tuber-size dependent mortality costs associated with burial depth. Tuber size and burial depth are explained by a trade-off between sprouting mortality costs, the resources needed to make large tubers and burial-depth dependent predation risk

this relationship is particularly strong. However, the outcome of the trade off between sprouting success and predation risk has not always been the same. Comparing our recent Lauwersmeer measurements on tuber burial depth with those of Beekman et al. (1991), shortly after the area was taken into use by Bewick's Swans, indicate that tubers of a given size tended to be buried approximately $10 \mathrm{~cm}$ higher up in the sediment (Fig. 3). Thus in recent times, predation pressure apparently weighs heavier in the trade off than sprouting success. There is a genetic component to tuber size and burial depth (Hangelbroek \& Santamaría, 2004), and genotypic selection can therefore be held responsible for the change in tuber burial depth within 20 years. However, this need not necessarily be the case, since tuber size and burial depth are also strongly maternally determined (Hangelbroek \& Santamaría, 2004).

Plant production in the face of herbivory

Despite sometimes intensive grazing on tubers, Fennel Pondweed stands regain similar tuber densities as when grazing is absent within one growing season. Experiments have shown that per capita tuber production (i.e., the annual total production of tubers divided by initial tuber 
density) is negatively related to initial tuber density at the start of the growing season, selfshading being one of the most likely candidates explaining the lowered production at high plant densities (Rodríguez-Gironés et al., 2003). Modelling studies have indicated that this effect may easily lead to compensation if swans graze the tuber stocks down to a certain level (Jonzén et al., 2002). Indeed, field work confirmed that grazing levels by swans are generally such that compensation occurs and tuber yield to the swans is large (Nolet 2004). Also in the absence of subsidiary (agricultural) food sources this will probably remain the case. The swans are predicted to graze down the tuber bank to a lower level, namely that at which foraging costs would exceed food intake rather than to a level at which pondweed foraging yields as much as foraging on the surrounding beet fields (Nolet et al., 2002). However, at this lower level, compensatory growth of the pondweed will also be higher. Hence, Fennel Pondweed is very well capable of withstanding grazing of the tuber stocks by swans.

\section{Herbivores as vectors for dispersal}

"But the wide distribution of fresh-water plants (...) apparently depends in main part on the wide dispersal of their seeds (...) by animals, more especially by fresh-water birds, which have great powers of flight, and naturally travel from one piece of water to another." (Darwin, 1859). Indeed, of many water plant species the seeds may stick to the feathers or may be transported in the guts of water birds (see Clausen et al., 2002). Most ingested seeds are digested wholly or partly, and are no longer viable after passing the digestive tract. Still, for Fennel Pondweed it has been shown that some seeds may remain in the digestive tract of ducks for as long as $54 \mathrm{~h}$ while retaining viability (Charalambidou et al., 2005). This is more than the calculated maximum flight durations of long-distance flights, so this would mean that such seeds might potentially travel 3000-3500 km (i.e., the maximum flight distance) on board of a migrating duck (Clausen et al., 2002). Hence, there is a small chance for a seed to survive such a long-distance dispersal and to successfully germinate. The next question is what potential such a seed has to compete with locally adapted conspecifics in a foreign environment. For Fennel Pondweed Santamaría et al. (2003) conducted reciprocal transplant experiments to investigate in how far clones from various regions in Europe thrived at distant sites. They showed that northern European clones tended to be much better tuber producers than Mediterranean clones, which relied almost exclusively on sexual reproduction through seeds. Although seeds have a much higher survival to desiccation than tubers, with their large nutrient stores tubers probably have a much better competitive ability to seeds. This led Santamaría et al. (2003) to hypothesise that northern clones could successfully compete with southern clones as long as no drought would strike, allowing a steady gene flow from northern to southern Europe along the flyways of migratory waterfowl. Gene flow in the opposite direction is thought to be less likely.

Whether this hypothesis holds still remains to be tested, yet, evidence for migratory waterfowl being an important vector for dispersal now comes from a number of population genetic studies. Mader et al. (1998) showed that for Fennel Pondweed at sites not visited by Bewick's Swans a clear correlation exists between genetic distance and geographic distance, indicating isolation by distance. However, for Fennel Pondweed from populations situated along the main NE-SW migratory flyway of waterfowl in Europe, this was not the case (Fig. 4). Furthermore, individual clones from nearby populations were more diverse along the flyway than outside the flyway. These data indicate more mixing among populations along the flyway, possibly as a result of migratory waterfowl connecting these populations. Similarly, genetic differentiation among $P$. pectinatus populations around the Baltic Sea basin increased with geographical distance, but this effect was smaller along the southeastern Swedish coast, where most water bird traffic took place. Presumably these birds acted as dispersal vectors for the plant (King et al., 2002).

\section{Plant competition under herbivory}

For terrestrial herbivores it is well established that they can affect the composition of the 


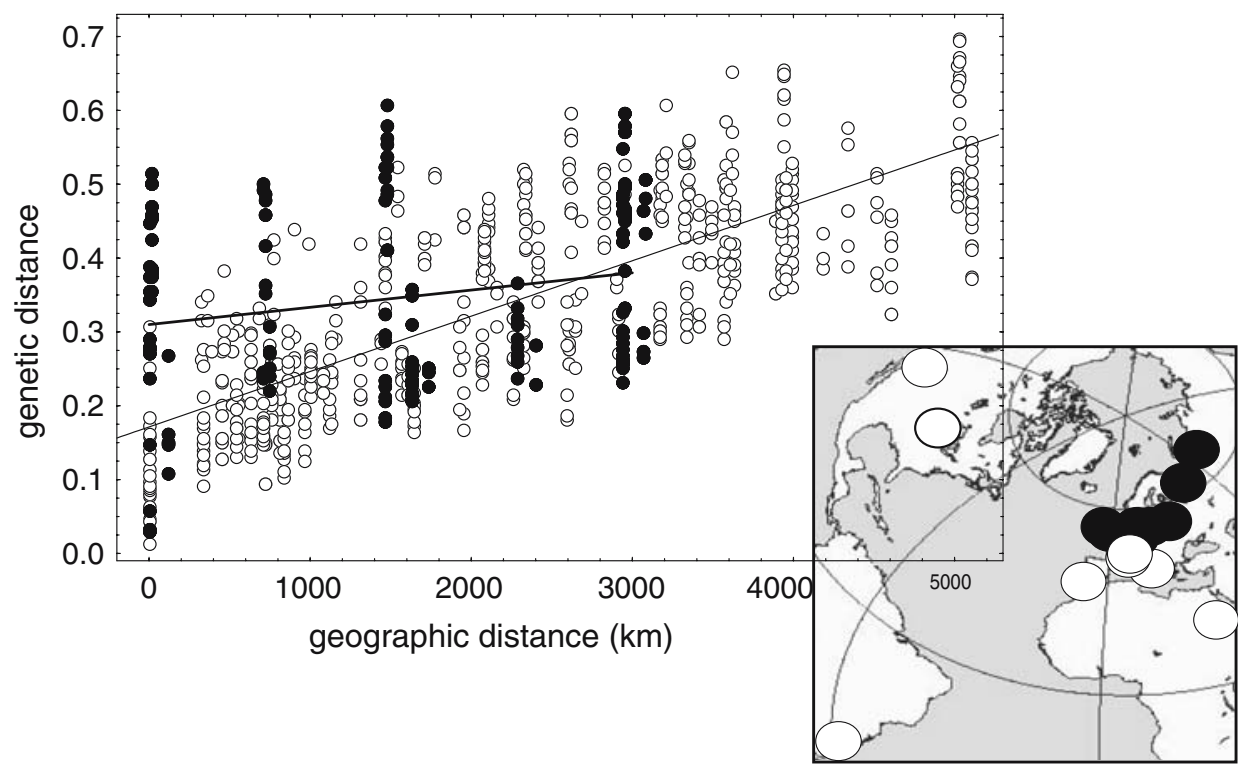

Fig. 4 Correlation of genetic distances of Fennel Pondweed (calculated from 0/1 matrix of RAPD data) versus geographic distances between the sites where pondweed samples were collected. Open symbols represent samples from non-swan-visited populations and closed symbols

vegetation, especially by removing the competitive plant dominant (Pacala \& Crawley, 1992; Olff \& Ritchie, 1998). It is well established for terrestrial systems that herbivores may maintain specific vegetations, grassland systems being the most renown example. Among water birds, geese are known to create so-called grazing lawns through repeated grazing. These grazing lawns have a specific vegetation composition of plants tolerating grazing, at the same time providing a high and sustainable yield to the geese (Person et al., 2003). Similar phenomena may also apply to aquatic vegetations (Santamaría, 2002).

Fennel Pondweed and Perfoliate Pondweed ( $P$. perfoliatus) can often be found in close proximity, Perfoliate Pondweed often occuring in somewhat deeper water than Fennel Pondweed. However, there are several areas where Perfoliate Pondweed occurs in shallow as well as deep waters, while Fennel Pondweed is predominant at intermediate depths. This is the case in the Pechora Delta, an important staging site for Bewick's swans in northern Russia, and in southern Sweden. We therefore conducted an experiment to learn if this typical distribution is related to the high tuber grazing intensity by Bewick's represent samples from swan-visited populations. The heavy and thin line represent correlations for swan visited and non-swan visited populations, respectively (redrawn from Mader et al., 1998)

Swans in both areas (Sandsten \& Klaassen, 2002). This hypothesis originated through the observation that swans prefer intermediate water depths, where the water is deep enough to uproot the tubers out of the sediment by trampling but where at the same time the water is shallow enough for the swans to reach to the uprooted tubers on the bottom with their beak. In early spring Perfoliate Pondweed stolons were planted in exclosures at intermediate water depths and let to grow. Just before the swans arrived some of these exclosures were removed. The subsequent grazing by notably Bewick's Swans had a dramatic effect. Nearly all the Perfoliate Pondweed was wiped out in the unprotected sites whereas in the protected sites the Perfoliate Pondweed continued to proliferate (Sandsten \& Klaassen, 2002). Fennel Pondweed tubers that escape predation have a high chance of sprouting in the following spring. However, because of their size and structure the stolons and roots of Perfoliate Pondweed are probably more easily detected and, if not eaten, damaged.

Swans, however, not always promote their main food plant $P$. pectinatus, especially not when it is the competitive dominant. This may explain why grazing by Trumpeter Swans (Cygnus 
buccinator) was demonstrated to increase submerged plant species richness in pools dominated by $P$. pectinatus (LaMontagne et al., 2003). It may also explain why charophytes can displace canopy-forming $P$. pectinatus in shallow turbid lakes after oligotrophication. Due to eutrophication many shallow lakes like the Veluwemeer lost many of its submerged macrophytes during the 1960 s and 1970 s, until only $P$. pectinatus was remaining (Van Vierssen et al., 1994). During the recovery phase $P$. pectinatus was largely displaced by charophytes, notably Chara aspera (Van den Berg et al., 2003). Competition for inorganic carbon may lead to alternative states in which either species is dominant (Van Nes et al., 2003), but why charophytes can displace canopy-forming $P$. pectinatus in such shallow systems when turbidity is reduced is not understood (Van den Berg et al., 1998). Possibly herbivory by water birds, which presumably mainly affects $P$. pectinatus, may explain this switch (Van den Berg et al., 2003). In theory, Bewick's Swans additionally feeding on Chara bulbils (Noordhuis et al., 2002) would be able to deplete the $P$. pectinatus tubers down to very low levels. Chara would then affect $P$. pectinatus negatively in an indirect way through supporting their shared enemy (i.e., apparent competition). The hypothesis that remains to be tested is whether bird grazing tips the balance from a competitive advantage of $P$. pectinatus to that of $C$. aspera. In that way water birds would indirectly promote the clear water state of a shallow lake.

\section{Final caveat}

One of the points we wanted to make is the importance of aquatic plants for waterfowl. Despite the increased reliance on agricultural crops and their remains, aquatic vegetations form an important food source for many birds. Several species, like Bewick's Swan, cannot do without aquatic plants during migration, which is among the most energy craving periods during the annual cycle. In making our point on the importance of aquatic macrophytes for waterfowl, the focus has been mainly on the need to fulfil their energy requirements. Although of prime importance, foraging is not exclusively a matter of fulfilling energy needs. Also the requirements for (specific) proteins, essential fatty acids and other essential nutrients elements should be met. For waterfowl, it might be easier to maintain a balanced dietary intake while foraging in (semi-) natural environments than while foraging on agricultural fields (cf. Prop \& Black, 1998). Fitness consequences of dietary composition and the importance of natural wetlands to meet these demands require further study.

Water birds may have a range of effects on water plants. They may impact their population dynamics, meta-population dynamics, as well as vegetation composition. The consequences of these interactions for the plants involved may be labelled negative to positive. In part this depends on the species of plants involved, but it tends to depend mostly on the perspective one takes in viewing these interactions. By grazing, waterfowl may change the competitive ability of plant species or increase their dispersal rate. Thus the nature of these plant-animal interactions are often perspective dependent. The ultimate outcome of these interactions for the plants, i.e. in terms of plant fitness, depends on the balance between these various interactive processes, which are probably context dependent (Hay et al., 2004). Migrating Bewick's swans might in fact regularly visit the same foraging sites where they harvest the re-growth of the plants time and again. One could thus potentially view Bewick's swans as "nomadic farmers". Therefore, for the case of the interaction between Bewick's Swans and Fennel Pondweed the picture starts to emerge that this often may be a mutualistic relationship were ultimately both the swan and the plant benefit from their interactions.

Acknowledgements A warm thanks to all members of the department of Plant-Animal Interactions for the many stimulating discussions, and their enthusiasm and efforts in conducting the research that formed the basis of this publication. Also the views of Ruurd Noordhuis and Luc de Meester on a previous version of this manuscript are greatly appreciated. This is publication 3995, NIOOKNAW, Centre for Limnology, Nieuwersluis, The Netherlands and publication 479 of the Centre for Wetland Ecology. 


\section{References}

Abraham, K. F., R. L. Jefferies \& R. T. Alisauskas, 2005. The dynamics of landscape change and snow geese in mid-continent North America. Global Change Biology 11: 841-855.

Beekman, J. H., 1997. International censuses of the NW-European Bewick's Swan population, January 1990 and 1995. Swan Specialist Group Newsletter 6: 7-9.

Beekman, J. H., B. A. Nolet \& M. Klaassen, 2002. Skipping swans: fuelling rates and wind conditions determine differential use of migratory stopover sites of Bewick's Swans Cygnus bewickii. Ardea 90: 437-460.

Beekman, J. H., M. R. Van Eerden \& S. Dirksen, 1991. Bewick's Swans Cygnus columbianus bewickii utilising the changing resource of Potamogeton pectinatus during autumn in the Netherlands. Wildfowl Suppl. 1: 238-248.

Bellrose, F. C., 1980. Ducks, Geese and Swans in North America, 3 edition. Stackpole Books, Harrisburg, PA, USA.

Brouwer, G. A. \& L. Tinbergen, 1939. De verspreiding der kleine zwanen, Cygnus b. bewickii Yarr., in de Zuiderzee, vóór en na de verzoeting. Limosa 12: 1-18.

Charalambidou, I., L. Santamaría, C. Janssen \& B. A. Nolet, 2005. Digestive plasticity in Mallard ducks modulates dispersal probabilities of aquatic plants and crustaceans. Functional Ecology 19: 513-519.

Clausen, P., B. A. Nolet, A. D. Fox \& M. Klaassen, 2002. Long-distance endozoochorus dispersal of submerged macrophyte seeds by migratory waterbirds in northern Europe - a critical review of possibilities and limitations. Acta Oecologica 23: 191-203.

Coops, H., E. H. Van Nes, M. S. Van den Berg \& G. D. Butijn, 2002. Promoting low-canopy macrophytes to compromise conservation and recreational navigation in a shallow lake. Aquatic Ecology 36: 483-492.

Darwin, C., 1859. On the origin of species by means of natural selection, or the preservation of favoured races in the struggle for life. John Murray: London.

Declerck, S., J. Vandekerkhove, L. Johansson, K. Muylaert, J. M. Conde-Porcuna, K. Van der Gucht, C. PerezMartinez, T. Lauridsen, K. Schwenk, G. Zwart, W. Rommens, J. Lopez-Ramos, E. Jeppesen, W. Vyverman, L. Brendonck \& L. De Meester, 2005. Multigroup biodiversity in shallow lakes along gradients of phosphorus and water plant cover. Ecology 86: 19051915.

Dirksen, S., J. H. Beekman \& T. H. Slagboom, 1991. Bewick's Swans Cygnus columbianus bewickii in the Netherlands: numbers, distribution and food choice during the wintering season. Wildfowl Suppl. 1: 228-237.

Engelhardt, K. A. M. \& M. E. Ritchie, 2002. The effect of aquatic plant species richness on wetland ecosystem processes. Ecology 83: 2911-2924.

Hangelbroek, H. H. \& L. Santamaría, 2004. Regulation of propagule size in the aquatic pseudo-annual Potamogeton pectinatus: are genetic and maternal non- genetic effects additive? Evolutionary Ecology Research 6: 147-161.

Hay, M. E., J. D. Parker, D. E. Burkepile, C. C. Caudill, A. E. Wilson, Z. P. Hallinan, \& A. D. Chequer, 2004. Mutualisms and aquatic community structure: the enemy of my enemy is my friend. Annual Review of Ecology Evolution and Systematics 35: 175-197.

Jefferies, R. L., A. P. Jano \& K. F. Abraham, 2006. A biotic agent promotes large-scale catastrophic change in the coastal marshes of Hudson Bay. Journal of Ecology 94: 234-242.

Jefferies, R. L., D. R. Klein \& G. R. Shaver, 1994. Vertebrate herbivores and northern plant communities: reciprocal influences and responses. Oikos 71: 193-206.

Jonzén, N., B. A. Nolet, L. Santamaría \& M. G. E. Svensson, 2002. Seasonal herbivory and mortality compensation in a swan-pondweed system. Ecological Modelling 147: 209-219.

Kerbes, R. H., P. M. Kotanen \& R. L. Jefferies, 1990. Destruction of wetland habitats by lesser snow geese: a keystone species on the west coast of Hudson Bay. Journal of Applied Ecology 27: 242-258.

King, R. A., R. J. Gornall C. D. Preston \& J. M. Croft, 2002. Population differentiation of Potamogeton pectinatus in the Baltic Sea with reference to waterfowl dispersal. Molecular Ecology 11: 1947-1956.

Knapton, R. W. \& S. A. Petrie, 1999. Changes in distribution and abundance of submerged macrophytes in the Inner Bay at Long Point, Lake Erie: implications for foraging waterfowl. Journal of Great Lakes Research 25: 783-798.

LaMontagne, J., L. J. Jackson \& R. M. R. Barclay, 2003. Compensatory growth responses of Potamogeton pectinatus to foraging by migrating trumpeter swans in spring stop over areas. Aquatic Botany 76: 235-244.

Lauridsen, T. L., E. Jeppesen \& F. Østergaard Andersen, 1993. Colonization of submerged macrophytes in shallow fish manipulated Lake Væng: impact of sediment composition and waterfowl grazing. Aquatic Botany 46: 1-15.

Lodge, D. M., 1991. Herbivory on freshwater macrophytes. Aquatic Botany 41: 195-224.

Lodge, D. M., G. Cronin, E. van Donk \& A. J. Froelich, 1998. Impact of herbivory on plant standing crop: comparisons among biomes, between vascular and nonvascular plants, and among freshwater herbivore taxa. In Jeppesen E., M. Søndergaard, M. Søndergaard, \& K. Christoffersen (eds), The Structuring Role of Submerged Macrophytes in Lakes. Springer, New York: 149-174.

Mader, E., W. Van Vierssen \& K. Schwenk, 1998. Clonal diversity in the submerged macrophyte Potamogeton pectinatus L. inferred from nuclear and cytoplasmic variation. Aquatic Botany 62: 147-160.

Merne, O. J., 1972. Bewick's Swans feeding on waste potatoes and other agricultural crops. British Birds 65: 394-395.

Miyabayashi, Y. \& T. Mundkur, 1999. Atlas of Key Sites for Anatidae in the East Asian Flyway. Wetland 
International. http://www.jawgp.org/anet/aaa1999/ aaaendx.htm.

Mullié, W. C. \& E. P. R. Poorter, 1977. Aantallen, verspreiding en terreinkeus van de kleine zwaan bij vijf landelijke tellingen in 1976 en 1977 . Watervogels 2: 85-96.

Nolet, B. A., 2004. Overcompensation and grazing optimisation in a swan-pondweed system? Freshwater Biology 49: 1391-1399.

Nolet, B. A., V. A. Andreev, P. Clausen, M. J. M. Poot \& E. G. J. Wessel, 2001. Significance of the White Sea as a stopover for Bewick's Swans Cygnus columbianus bewickii in spring. Ibis 143: 63-71.

Nolet, B. A., R. M. Bevan, M. Klaassen, O. Langevoord \& Y. G. J. T. Van der Heijden, 2002. Habitat switching by Bewick's swans: maximisation of average longterm energy gain? Journal of Animal Ecology 71: 979-993.

Nolet, B. A., V. N. Fuld \& M. E. C. Van Rijswijk, 2006. Foraging costs and accessibility as determinants of giving-up densities in a swan-pondweed system. Oikos 112: 353-362.

Nolet, B. A. \& M. Klaassen, 2005. Time and energy constraints in demanding phases of the annual cycle: an example of time limitation in refuelling migratory swans. Oikos 111: 302-310.

Noordhuis, R., D. T. Van der Molen \& M. S. Van den Berg, 2002. Response of herbivorous water-birds to the return of Chara in Lake Veluwe, The Netherlands. Aquatic Botany 72: 349-367.

Olff, H. \& M. E. Ritchie, 1998. Effects of herbivores on grassland plant diversity. Trends in Ecology and Evolution 13: 261-265.

Pacala, S. W. \& M. J. Crawley, 1992. Herbivores and plant diversity. American Naturalist 140: 243-260.

Perrow, M. R., J. H. Schutten, J. R. Howes, T. Holzer, F. J. Madgwick \& A. J. D. Jowitt, 1997. Interactions between coot (Fulica atra) and submerged macrophytes: the role of birds in the restoration process. Hydrobiologia 342/343: 241-255.

Person, B. T., M. P. Herzog, R. W. Ruess, J. S. Sedinger, R. M. Anthony \& C. A. Babcock, 2003. Feedback dynamics of grazing lawns: coupling vegetation change with animal growth. Oecologia 135: 583-592.

Polunin, N. V. C., 1984. The decomposition of emergent macrophytes in fresh-water. Advances in Ecological Research 14: 115-166.

Prop, J. \& J. M. Black, 1998. Food intake, body reserves and reproductive success of barnacle geese Branta leucopsis staging in different habitats. Norsk Polarinstitutt Skrifter 200: 175-193.

Rodríguez-Gironés, M. A., H. Sandsten \& L. Santamaría, 2003. Asymmetric competition and the evolution of propagule size. Journal of Ecology 91: 554-562.
Sandsten, H. \& M. Klaassen, 2002. Waterfowl foraging affects competitive ability and distribution of Potamogeton pectinatus and $P$. perfoliatus. In Sandsten H. (ed), Waterfowl Herbivory on Submerged Macrophytes in Eutrophic Lakes. Lund University, Lund.

Santamaría, L., 2002. Selective waterfowl herbivory affects species dominance in a submerged plant community. Archiv für Hydrobiologie 153: 353-365.

Santamaría, L., J. Figuerola, J. J. Pilon, M. Mjelde, A. J. Green, T. de Boer, R. A. King \& R. J. Gornall, 2003. Plant performance across latitude: the role of plasticity and local adaptation in an aquatic plant. Ecology 84: 2454-2461.

Santamaría, L. \& M. A. Rodríguez-Gironés, 2002. Hiding from swans: optimal burial depth of sago pondweed tubers foraged by Bewick's swans. Journal of Ecology 90: 303-315.

Scheffer, M., 1998. Ecology of Shallow Lakes. Chapman \& Hall, London [etc.].

Scott, D. A. \& P. M. Rose, 1996. Atlas of Anatidae Populations in Africa and Western Eurasia. Wetlands International Publication No. 41, Wageningen, The Netherlands.

Shelford, V. E., 1918. Conditions of coexistence. In Ward H. B. \& G. C. Whipple (eds), Freshwater Biology. John Wiley, New York: 21-60.

Søndergaard, M., L. Bruun, T. Lauridsen, E. Jeppesen \& T. V. Madsen, 1996. The impact of grazing waterfowl on submerged macrophytes: in situ experiments in a shallow eutrophic lake. Aquatic Botany 53: 73-84.

Van den Berg, M. S., H. Coops, J. Simons \& A. De Keizer, 1998. Competition between Chara aspera and Potamogeton pectinatus as a function of temperature and light. Aquatic Botany 60: 241-250.

Van den Berg, M. S., W. Joosse \& H. Coops, 2003. A statistical model predicting the occurrence and dynamics of submerged macrophytes in shallow lakes in the Netherlands. Hydrobiologia 506-509: 611-623.

Van Eerden, M. R., R. H. Drent, J. Stahl \& J. P. Bakker, 2005. Connecting seas: western Palaearctic continental flyway for water birds in the perspective of changing land use and climate. Global Change Biology 11: 894-908.

Van Nes, E. H., M. Scheffer, M. S. Van den Berg \& H. Coops, 2003. Charisma: a spatial explicit simulation model of submerged macrophytes. Ecological Modelling 159: 103-116.

Van Vierssen, W., M. Hootsmans \& J. Vermaat, 1994. Lake Veluwe, a Macrophyte-dominated System under Eutrophication Stress. Kluwer Academic Publishers, Dordrecht [etc.].

Wetzel, R. G., 1983. Limnology, 2nd edition. W.B. Saunders, Philadelphia, PA, USA. 